\title{
Revision of the genus Hoplosauris Butler 1882 (Lepidoptera: Geometridae)
}

\author{
LUIS E. PARRA, MARÍA C. JIMÉNEZ-URRUTIA \& CARLOS ZAMORA-MANZUR \\ Departamento de Zoología, Facultad de Ciencias Naturales y Oceanográficas, Universidad de Concepción, Casilla 160-C, \\ Concepción, Chile. E-mail: luparra@udec.cl
}

\begin{abstract}
The genus Hoplosauris Butler 1882 is reviewed and redefined. Species belonging to the genera Notholoba syn. nov. and Physoloba Warren (1908) are incorporated into Hoplosauris, and the species Physoloba griseofasciata is maintained Physoloba as its type species. The following eight species are recognized in Hoplosauris: H. heliconoides Butler, 1882; H. schausi (Warren 1908) comb. nov.; H. valeria Butler 1893; H. indistincta (Butler, 1882) comb. nov.; H. macarenae Parra sp. nov.; H. granitata (Fletcher 1953) comb. nov.; H. pachrophylloides Parra sp. nov.; H. mabillei Parra sp. nov. Synapomorphic characters supporting monophyly of Hoplosauris include vesicle of anal margin of the male hindwings small, corpus bursae striated, internal surface of corpus bursae with microspines, and valvae with androconia subapically. Adult wing patterns and genitalia are illustrated, and geographic distributions discussed.
\end{abstract}

Key words: Larentiinae, Trichopterygini, new combinations, Notholoba, Physoloba, Hoplosauris mabillei, H. pachrophylloides, $H$. macarenae, $H$. granitata, $H$. heliconoides, $H$. valeria, $H$. schausi, $H$. indistincta, Chile, Argentina

\section{Introduction}

The Larentiinae are the second most diverse subfamily of Geometridae, and they are also the most speciesrich group in temperate regions and higher elevated zones of tropical areas (Scoble 1995). Larentiinae are relatively well known in the sub-Andean region (Morrone 2001), particularly the tribes Eupitheciini and Trichopterygini (Rindge 1987; Parra 1997). According to Angulo and Casanueva (1981) this subfamily is represented in Chile by 36 genera and 87 species. Research carried out by Parra $(1991,1996)$, Parra \& IbarraVidal (1997) and Parra \& Santos-Salas $(1991,1992)$ includes updated reviews on the tribe Trichopterygini. Prout (1912) defined the Trichopterygini by males males having lobe, lapel or vesicle in the base of the hindwings. As a tribe, Trichopterygini are distributed worldwide and are present in all faunistic regions (Dugdale 1980). In the southern Andean region, the Trichopterygini include 9 endemic genera (Parra 1997). Additionally, there are 3 genera which are also represented in this region: Hoplosauris Butler 1882; Notholoba Warren 1908 and Physoloba Warren 1908. Notholoba and Physoloba can be distinguished from other genera by having a vesicle on the male hindwing, whereas Hoplosauris bears a lapel.

Hoplosauris Butler (1882) was erected based on the type species $H$. heliconoides, which was defined by wing pattern of the males and females. Butler (1882) suggested the genus was closely related to Tatosoma from New Zealand, and he included H. alba Btl. and H. moesta Btl. in his concept of Hoplosauris. Scoble (1999), in his world catalogue of geometrid moths, listed five additional species under this genus: $H$. analogica (Prout 1926), H. fragmentata (Dognin 1906), H. imbricaria (Felder \& Rogenhofer 1875), $H$. limnetes (Prout 1923) and H. perornata (Mabille 1885), on the basis of information gathered by Scoble along with examination of specimens at the British Museum of Natural History (BMNH). Additionally, Butler (1893) described H. valeria as a new species for Chile, which Scoble (1999) as a valid species of an unnamed genus of Larentiinae. 
The taxonomic history of Notholoba and Physoloba is limited. Scoble (1999) listed two Chilean species in Notholoba: N. edelmira (Butler 1882), previously included in the genus Hoplosauris; and N. schausi Warren, 1908. Physoloba (sensu Scoble 1999) is defined by five species of which four are described from Chile: Physoloba indistincta (Butler 1882), P. insularis (Aurivillius et al. 1922), P. multivirgulata (Mabille 1885) and $P$. granitata Fletcher 1953. The fifth species is $P$. griseofasciata Warren (1908), the type species of Physoloba genus, with type locality of Parana, Brazil.

This paper examines relationships among species in Hoplosauris, Notholoba and Physoloba, and includes analysis of type material. Most species belonging to these three genera are reunited under Hoplosauris. A total of 220 specimens were examined from the following instituional collections: Museo de Zoología de la Universidad de Concepción (MZUC-UCCC); Museo de Historia Natural de Santiago, Chile (MNHN); Instituto de Entomología de la Universidad Metropolitana de Ciencias de la Educación (Santiago) (UMCE) collection; The British Museum of Natural History, London, England (BMNH); Instituto Miguel Lillo, Universidad Nacional de Tucumán, S.M. de Tucumán, Argentina (IMLT) and the Smithsonian Institution, Washington, U.S.A. (USNM).

\section{Hoplosauris Butler 1882}

Hoplosauris Butler 1882: 399.

Notholoba Warren 1908: 103. syn. nov.

Type species: Hoplosauris heliconoides Butler 1882, types: 1 male, Baños de Chillán, 1 female, Corral, Chile (BMNH). Notholoba schausi Warren 1908, syntypes: 1 male and 1 female, Chile (USNM).

Diagnosis: In the male, the anal margin of the hindwings is reduced with a tuft of hair like scales or with a small vesiculae. Valvae sub-rectangular, with androconia at subapical position, vesica with one or two compact groups of compacted spines. Female with corpus bursae spherical or elongated. Internal surface with microspines arranged in different regions. Synapormorphies supporting monophyly of the genus are: a small vesicule and/or a lapel in the anal margin of the male's hindwings, striate areas and microspines on the internal surface of the corpus bursae; and androconia in the subapical region of the valvae.

Description: Antennae sub-apically thickened in both male and female. Thorax and abdomen with brownish scales varying from reddish, orange to greenish tones. Hind wings with a discal spot always present on the dorsal surface. Anal margin of the male hindwings with a concave or convex hairy vesicle or just with hairy scales. Tibial spur formula 0-2-4 in both sexes. Female genitalia, corpus bursae with spherical or elongated, slightly sclerotized, with microspines on internal surface. Sterigma membranous. Male genitalia with sub-rectangular valvae. Androconia at subapical position of valvae. Aedeagus tubular. Vesica with one or two groups of cornuti.

Distribution: the genus occurs between latitudes $33^{\circ} \mathrm{S}$ and $52^{\circ} \mathrm{S}$, in Valparaíso and Magallanes provinces (Chile) and Neuquén (Argentina).

\section{Checklist of Hoplosauris}

Hoplosauris granitata (Fletcher 1953) comb. nov.

Physoloba granitata Fletcher 1953

Hoplosauris heliconoides Butler 1882

Larentia multivirgulata Mabille 1885 syn. nov.

Lobophora multivirgulata (Mabille 1885) Mabille 1891

Physoloba multivirgulata (Mabille 1885) Fletcher 1953

Physoloba heliconoides (Butler 1882) Angulo \& Casanueva 1981

Hoplosauris indistincta (Butler 1882) comb. nov. 
Amathia indistincta Butler 1882

Physoloba indistincta (Butler 1882) Fletcher 1953

Rhopalodes viridularia Dognin 1906

Hoplosauris mabillei Parra sp. nov.

Hoplosauris pachrophylloides Parra sp. nov.

Hoplosauris schausi (Warren 1908) comb. nov.

Notholoba schausi Warren 1908

Hoplosauris macarenae Parra sp. nov.

Hoplosauris valeria Butler 1893

\section{Hoplosauris schausi (Warren 1908) comb. nov.}

Notholoba schausi Warren 1908: 103; Scoble 1999: 646.

Type. Notholoba schausi, syntypes: 1 male and 1 female, Chillán, Chile (USNM) (examined).

Material examined: (4 females, 9 males). Ñuble. 1 male \& 1 female, without types, Chillán, Chile (USNM); Las Trancas: 1 female, 8-1-1996 Beéche coll; 4 males, 8-1-1996 Beéche coll; Bulnes km 25: 1 male 27-11-1981 (MZUC-UCCC); Concepción. Concepción: 1 female, 2-11-1960 Gramar coll; 1 female, 13-092001 (MZUC-UCCC); Cautín. Termas río blanco: 1 male 3-1951 (MZUC-UCCC); Valdivia. Valdivia: 1 male, 22-1-1959 Krhamer coll; 1 male 6-2-1959 Krahmer coll. (MZUC-UCCC).

Diagnosis. Hoplosauris schausi can be distinguished from the other species of the genus by: spherical corpus bursae (autapomorphy); length of the ductus bursae approximately $1 / 8$ of the total length of the corpus bursae; straight uncus; and cornuti, a group of short and thick spines.

Redescription. Male (Figure 1a): Head: Antennae sub-apically thickened, covered by white scales mixed up with some brown scales. Frons and vertex covered mainly by white scales and few brown scales. Labial palpi with a brownish apex and white base. Thorax: dorsal surface of the thorax covered by brown and white scales. Patagia and tegula similalarly covered. Tegula with hair like scales extending posteriorly. Forewings: ground colour of upperside grey with slight brownish tinge, basal area brown, antemedial and postmedial lines dark brown, the latter crenulate, terminal area with dark brown shades. Discal mark dark brown. Ventral surface light brown. Hindwings: reduced and with hairy concave vesicle on anal margin; upperside light brown. Underside whitish. Discal mark dark brown. Coloration of abdomen similar to that of the thorax. Legs chequered dark brown and white. Female. similar to male, without reduced hindwings and without a hairy concave vesicle on the anal margin. Male genitalia (Figures 2a, c). Uncus straight and narrow, slightly setose, with acute apex, approximately equal to length of valvae, basis subtriangular. Valvae sub-rectangular, with androconia at sub-apical position. Costa slightly sclerotized. Ventral margin of the valvae transversally striate. Saccus semicircular. Aedeagus broad, tubular, vesica with a group of short and thick cornuti, approximately $1 /$ 3 the length of the aedeagus. Female genitalia (Figure 2b). Sterigma membranous. Corpus bursae subspherical, membranous, with microspines on internal surface, except for the most anterior part. Anterior apophyses approximately $1 / 4$ length apophyses posteriors. Ductus bursae short, 1/8 the length of corpus bursae. Ductus seminalis indistinguishable.

Distribution. This species occurs between $36^{\circ} \mathrm{S}$ and $40^{\circ} \mathrm{S}$, in the provinces of Nuble and Valdivia.

Flight period. Specimens were captured in September, November, January and March. There are no records for other months.

\section{Hoplosauris pachrophylloides Parra sp. nov.}

Type. Hoplosauris pachrophylloides, Holotype: 1 male Reserva Nacional Ñuble, Nuble, Chile 10-01-01, Ibarra Coll. Alotype: 1 female Reserva Nacional Ñuble, Ñuble Chile 10-01-01, Ibarra Coll. (MZUC-UCCC). 
Material examined (4 females, 11 males). Ñuble. Holotype: 1 male Reserva Nacional Ñuble 10-01-01, Ibarra Coll. Allotype: 1 female Reserva Nacional Ñuble, 10-01-01, Ibarra Coll (MZUC-UCCC). Paratypes: Reserva Nacional Ñuble guardería los Peucos: 3 males, 10-01-2001 Ibarra coll; Las Trancas: 2 males, 11-011996; 1 male 16-01 1996. Volcán Chillán: 3 males, 1-03-1979; 3 females, 3-03-1979 (MZUC-UCCC). Cautín. Termas río blanco: 1 female, 15-03-1952 (MZUC-UCCC).

Diagnosis. Hoplosauris pachrophylloides is differentiated from other species in the genus by the androconia formed by a tuft of simple hairs and some thick bristles in the male genitalia. The valval costa is strongly sclerotized. In the female genitalia the microspines are present on the posterior half of the corpus bursae. This last character is an autapomorphy for the species.
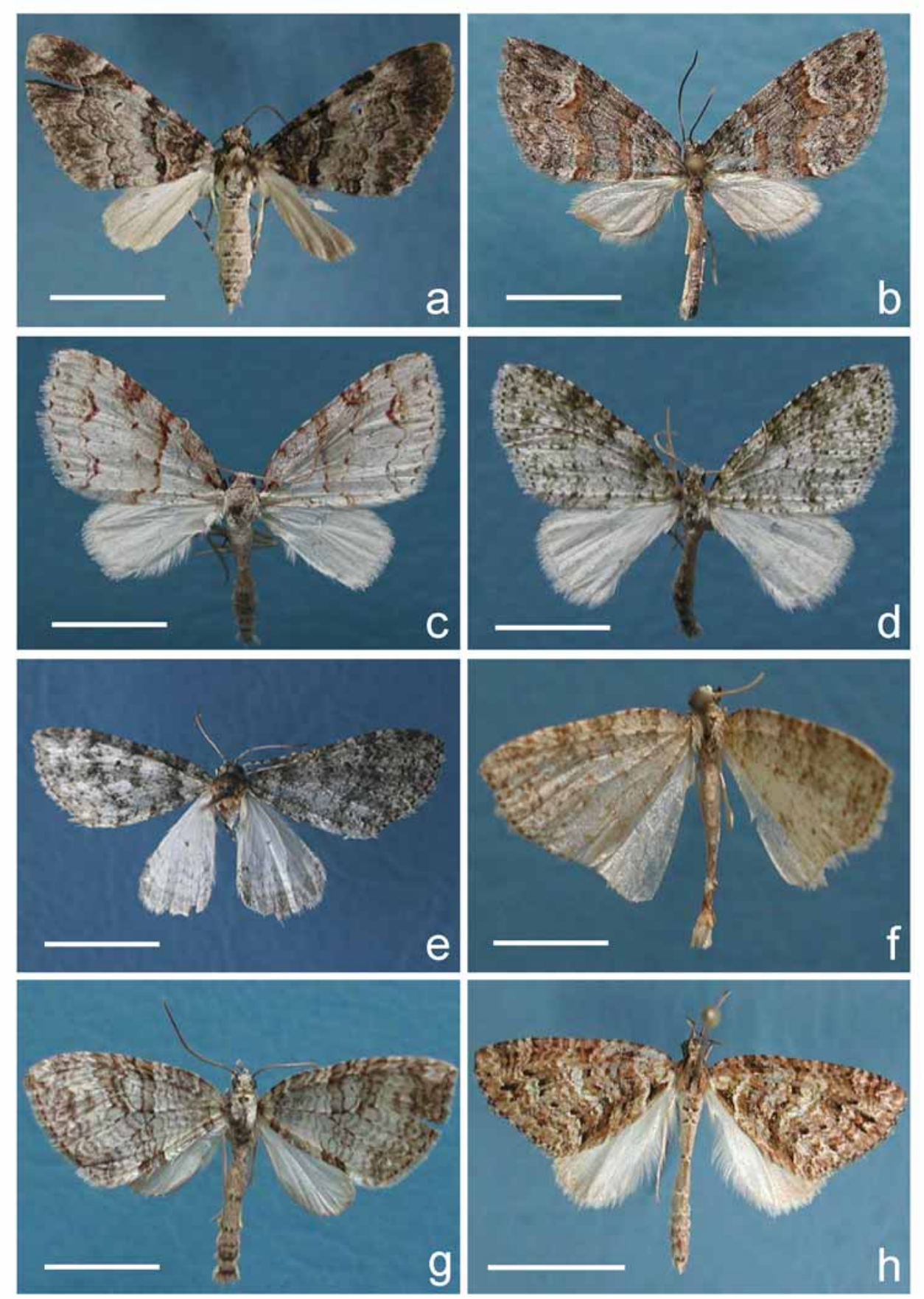

FIGURE 1. Habitus of males of Hoplosauris: a, H. schausi (Warren 1908) comb. nov.; b, H. pachrophylloides Parra sp. nov.; c, H. macarenae Parra sp. nov.; d, H. mabillei Parra sp. nov.; e, H. granitata (Fletcher 1953) comb. nov.; f, $H$. indistincta (Butler 1882) comb. nov.; g, H. heliconoides Butler 1882; h, H. valeria Butler 1893. Scale $1 \mathrm{~cm}$. 


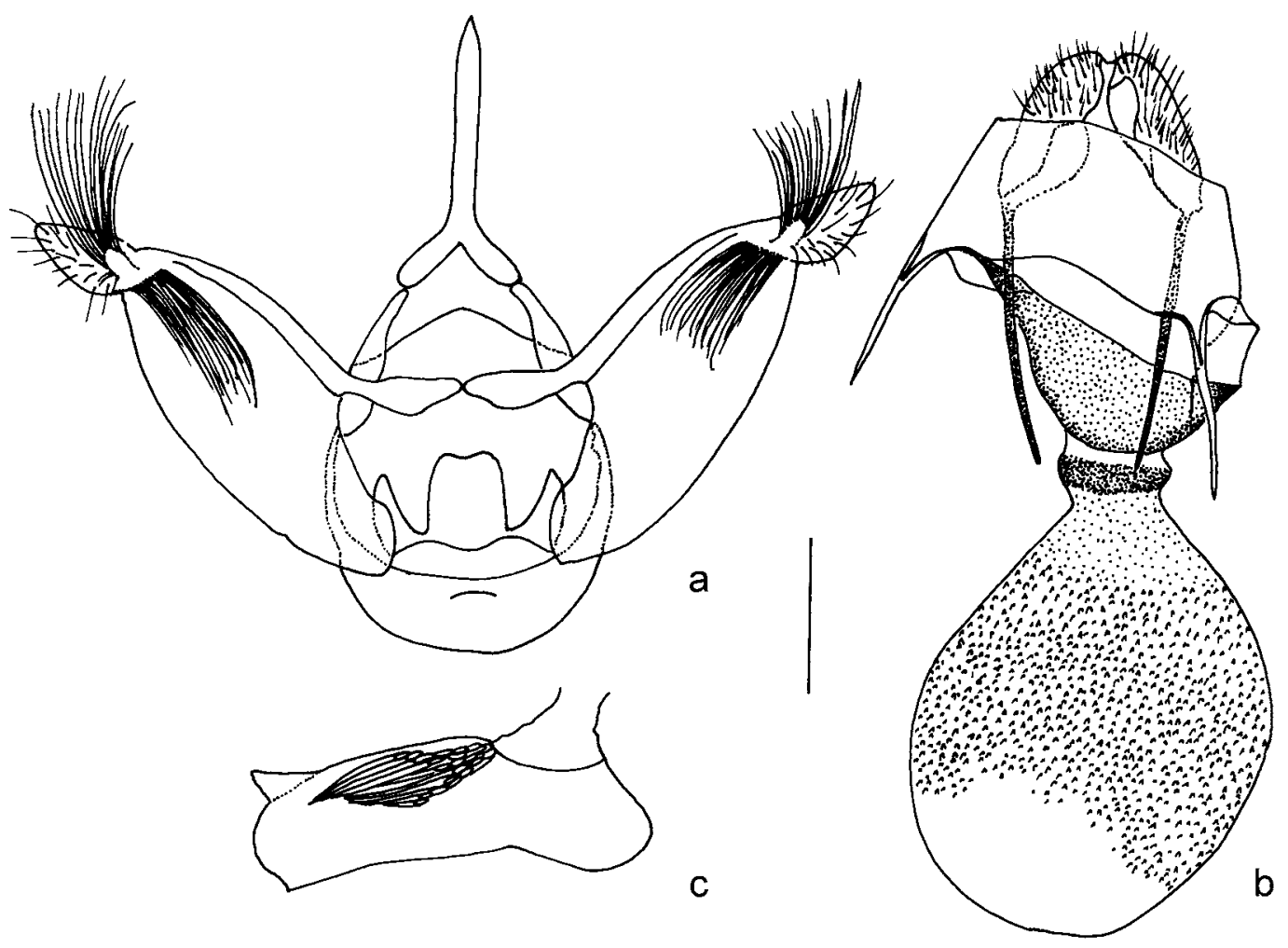

FIGURE 2. Genitalia of $H$. schausi: a, male genitalia in ventral view; b, female genitalia in ventral view; c, aedeagus in lateral view. Scale $1 \mathrm{~mm}$.

Description. Male (Figure 1b). Head: Antennae sub-apically thickened, covered by dark brown scales. Vertex and frons with dark and white scales. Labial palpi covered by scales with similar pattern to the forehead and vertex. Thorax: patagia and tegula covered by dark and white scales. Tegulae with enlarged piliform scales extending posteriorly. Forewings: upperside grey-brown. Basal line orange. Stripe, between basal and medial lines, dark brown. Medial line orange, surrounded by dark brown scales. Subterminal line orange. Terminal line formed by dark brown semicircles. Discal mark dark brown. Hindwings: reduced, with a hairy convex vesicle on the anal margin; upperside and underside white. Abdomen covered by white scales on its anterior region and dark grey scales towards its posterior region. Fore and second mid legs with white femur. Tibiae and tarsi with brown and white intercalated stripes. Hind legs white. Female. Head and thorax the same as the male. Forewings: upperside grey brown. Basal line dark brown. Middle stripe light brown. Medial line orange with its borders covered by dark brown scales. Subterminal line dark brown, with orange marks. Terminal line represented by dark brown semicircles. Discal mark dark brown. Underside light brown. Hindwing whitish. Without reduced hindwings and without a hairy concave vesicle on the anal margin. Legs: white, femur, tibiae and tarsi with intercalated dark brown and white scales. Male genitalia (Figures 3a, c). Uncus curved, slightly setose, acute apex, basis subtriangular, approximately $1 / 2$ the length of the valvae. Valvae sub-rectangular, with androconia at subapical position, androconia with some long and thick bristles. Costa strongly sclerotized. Ventral margin of the valvae with a small groove on its medium region. Saccus semicircular. Aedeagus, short stout, tubular, vesical with a group of long and fine spines, approximately $1 / 3$ the length of the aedeagus. Female genitalia (Figure 3b). Sterigma membranous. Corpus bursae elongated, tear drop shaped, membranous, slightly sclerotized medially, with microspines on its internal surface distributed medially and anteriorly. Ductus bursae approximately $1 / 4$ length of the corpus bursae. Anterior and posterior apophyses subequal. Ductus seminalis indistinguishable.

Distribution. This species occurs between the $36^{\circ} \mathrm{S}$ and $38^{\circ} \mathrm{S}$, in the provinces of Nuble and Cautín. 
Etymology. The name refers to the similarity to species belonging to the genus Pachrophylla (Larentiinae: Trichopterygini).

Flight period. Specimens were captured during the months of January and March. There are no records from other months.

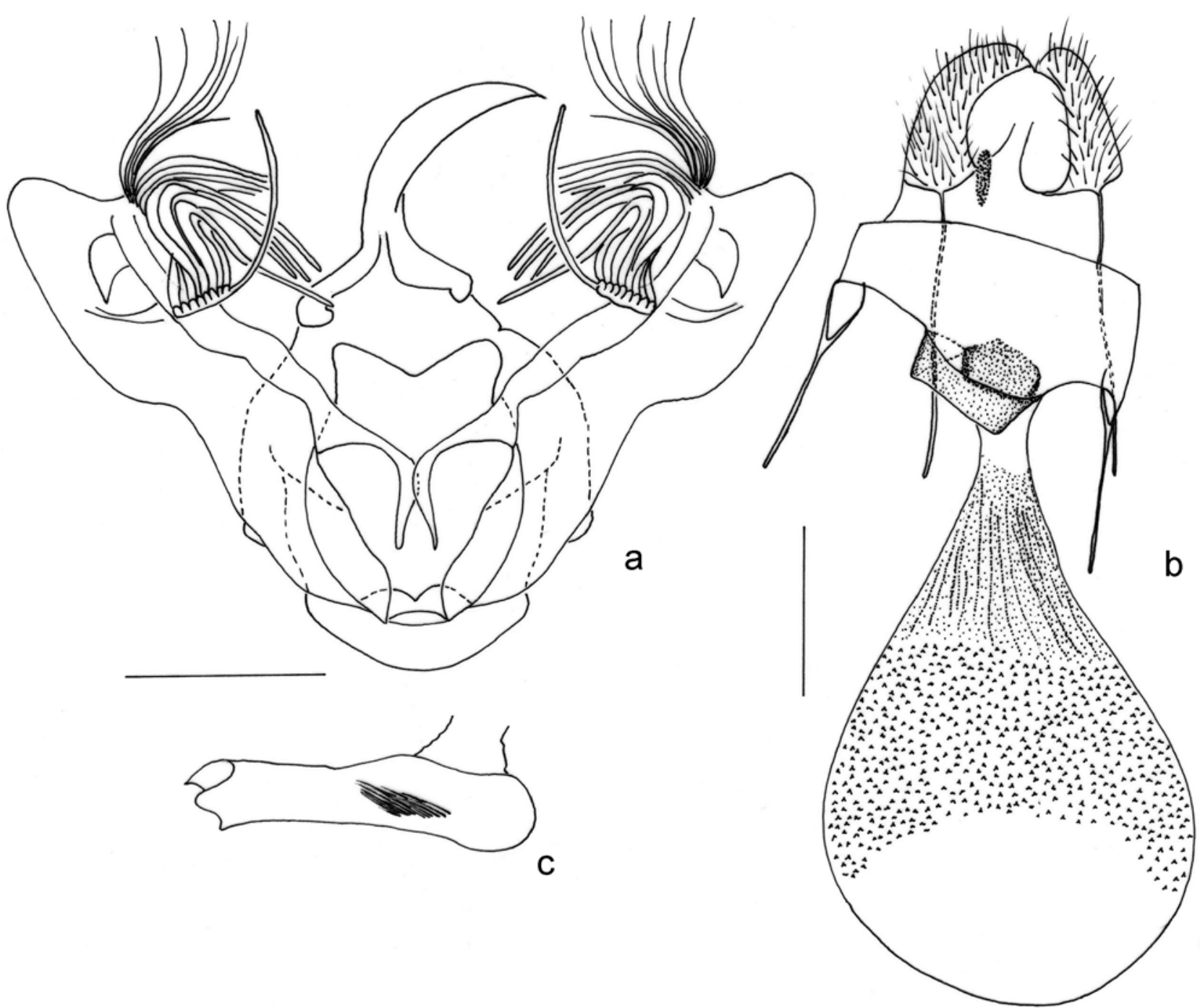

FIGURE 3. Genitalia of $H$. pachrophylloides: a, male genitalia in ventral view; b, female genitalia in ventral view; c, aedeagus in lateral view. Scale $1 \mathrm{~mm}$.

\section{Hoplosauris valeria Butler 1893}

Hoplosauris valeria Butler 1893: 463; Angulo \& Casanueva 1981: 29; Scoble 1999: 994.

Type: Hoplosauris valeria Holotype: 1 male Chile (BMNH) (examined).

Material examined (4 males). Holotype: 1 male Chile (BMNH). Valdivia. Valdivia: 1 male. 1 male, 5-111958 Krhamer coll. 1 male, 01-08-1986 Krahmer coll. (MZUC-UCCC); 3 males, 1-2008, Chile, Los Lagos, Huinay station (ZSM).

Diagnosis. Hoplosauris valeria can be distinguished from the other species of the genus by the small hairy lobule on the male hindwings, near the vesicle; and a tubular aedeagus, with a protuberance in its medial area. These two characters are the autapomorphies for the species.

Description. Male (Figure 1h). Head: Antennae sub-apically thickened, covered by dark brown scales. Vertex and frons with dark brown scales. Labial palpi with white apex and dark brown basis. Thorax: light 
brown scales and orange spots on its dorsal surface, as in patagia and tegula. Tegula with piliform scales extending posteriorly. Forewings: upperside orange with white spots on its medial zone. Medial line orange, surrounded by dark brown semicircles, darker towards the postmedial zone. Terminal line represented by dark brown semicircles. Underside light brown. Hindwings: upperside whitish, darker towards the costal margin of the wing. Underside whitish, with a light brown orange discal cell. Vesicle hairy and concave, with a small hairy lobule. Abdomen with white and dark brown scales on its basal zone. Fore and mid legs with white femur. Tibia and tarsus with dark brown and white intercalated stripes. Hind legs white. Female. Unknown. Male genitalia (Figures 4a, b). Uncus straight, setose, with acute apex, approximately $1 / 2$ to length of valvae. Valvae sub-rectangular, with androconia at subapical position. Costa slightly sclerotized. Ventral margin of the valvae with neckline on its subapical region. Aedeagus tubular, with a medial, dorsal protuberance, vesica with a group of short and thick cornuti, approximately $1 / 5$ the length of the aedeagus. Female genitalia. unknown.

Distribution. This species occurs from $40^{\circ}$ to $42^{\circ} \mathrm{S}$, Valdivia and Los Lagos provinces.

Flight period. Species captured during the months of August, November and January. There are no records from other months.

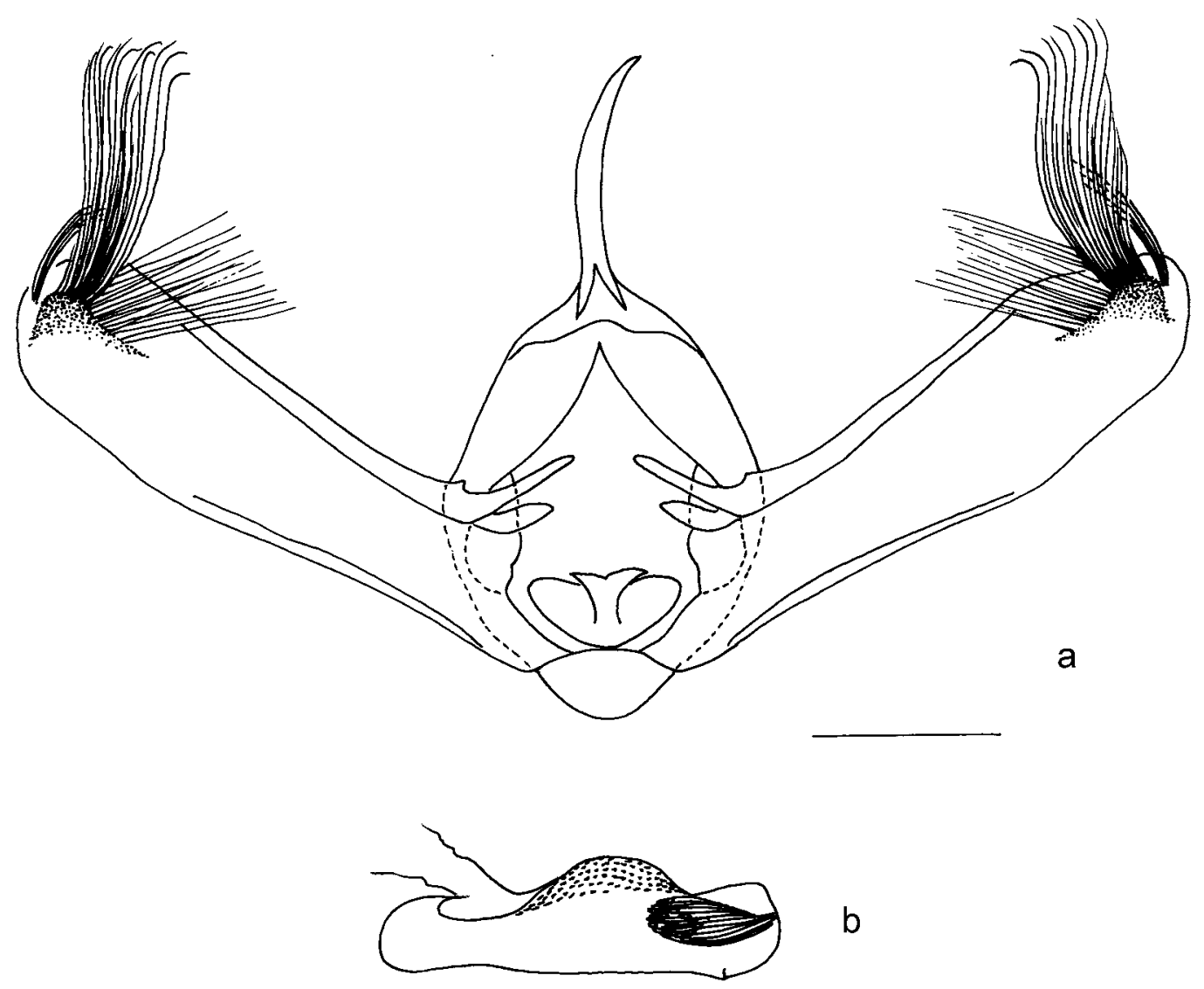

FIGURE 4. Genitalia of $H$. valeria: a, male genitalia in ventral view; b, aedeagus in lateral view. Scale $1 \mathrm{~mm}$.

\section{Hoplosauris macarenae Parra sp. nov.}

Type. Hoplosauris macarenae Holotype: 1 male Valdivia, Chile 14-09-84, Beéche coll. Allotype: 1 female Valdivia, Chile 10-64 Wagenknecht coll. (MZUC-UCCC)

Material examined (4 females, 9 males). Valdivia. Holotype: 1 male Valdivia, Chile 14-09-84, Beéche coll (MZUC-UCCC). Allotype: 1 female Valdivia, Chile 10-64 Wagenknecht coll. (UMCE). Paratypes: Valdivia: 1 male, 1888 Paulsen coll (MZUC-UCCC); 1 male, 01-1959 (MZUC-UCCC); 6 males, 30-04-1964 Wagenknecht coll; 3 females, 30-04-1964 Wagenknecht coll. (UMCE). 
Diagnosis. Hoplosauris macarenae can be distinguished from the other species of the genus by dark reddish scales covering the forewings, head and thorax. Male uncus with a blunt apex. Microspines located on the posterior half of the corpus bursae. These two characters are the autapomorphies for the species. Subrectangular saccus.

Description. Male (Figure 1c). Head: Antennae sub-apically thickened, covered by light reddish scales. Vertex and forehead with dark brown scales. Labial palpi with white apex and brown basis. Thorax: white, the same for the patagia and tegula. Tegula with piliform scales extending posteriorly. Forewings: upperside whitish. Basal line dark brown reddish. Stripe, located between the basal and medial lines, whitish. Medial line brown becoming reddish towards its basis, the rest light brown reddish. Medial line border brown becoming reddish towards the apex. Postmedial line dark brown reddish and orange towards its apex. Terminal line represented by brown semicircles. Discal mark brown reddish. Underside light brown reddish, lighter towards the anal margin of the wing. Hindwings: reduced and with a hairy concave vesicle; upperside whitish, underside whitish with a brown reddish discal cell. Abdomen whitish, with a tuft of scales on the sides of the medium region. Fore and mid legs with white and dark brown intercalated stripes. Hind legs white. Female. Similar to the male, without reduced hindwings and without a hairy concave vesicle on the anal margin. Male genitalia (Figures 5a, c). Uncus curved, with a blunt apex, subtriangular base, approximately $1 / 2$ to length of valvae. Valvae sub-rectangular, with androconia at sub-apical position. Costa slightly sclerotized. Ventral margin of the valvae with neckline on its subapical region. Saccus subrectangular. Aedeagus tubular, vesica with a group of short and thick cornuti (microspines); approximately $1 / 2$ the length of the aedeagus. Female genitalia (Figure 5b). Sterigma membranous. Corpus bursae sclerotized, elongated, striate, with microspines on its internal surface distributed on posteriorly. Ductus bursae $1 / 4$ the length of corpus bursae. Ductus seminalis indistinguishable.
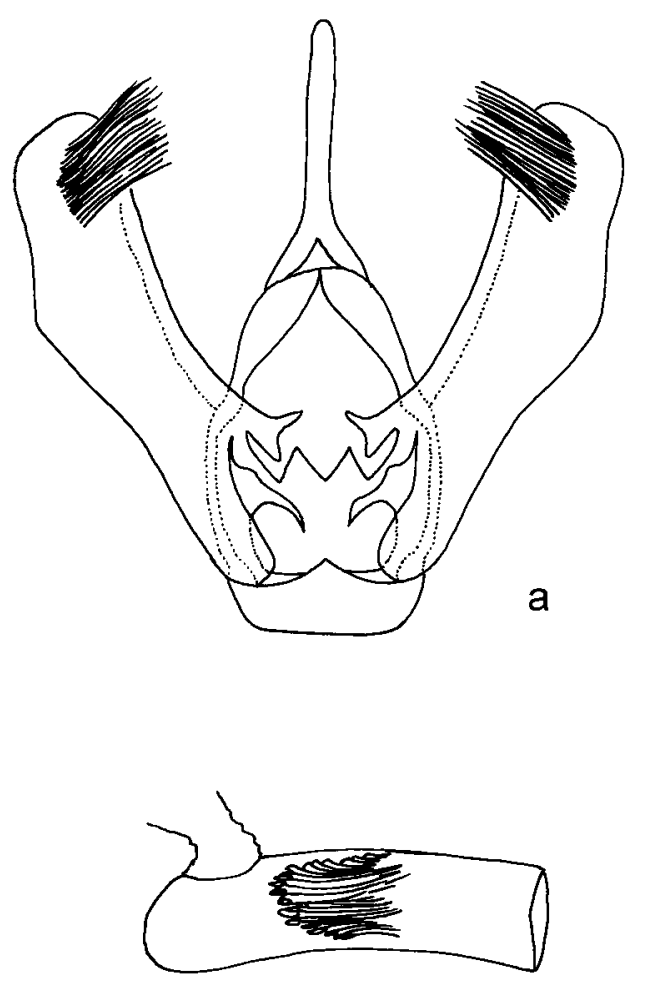

C

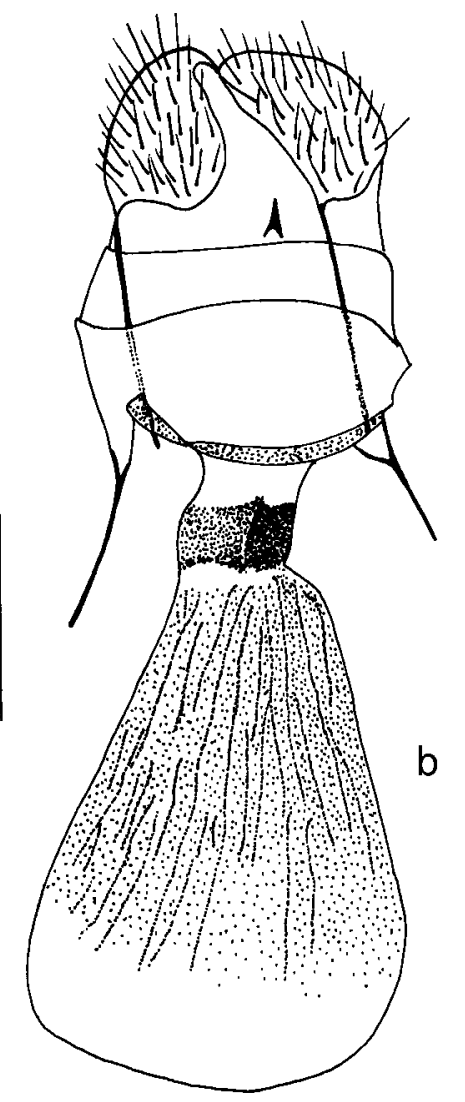

FIGURE 5. Genitalia of $H$. macarenae: a, male genitalia in ventral view; b, female genitalia in ventral view; c, aedeagus in lateral view. Scale $1 \mathrm{~mm}$. 
Distribution. This species is found around latitude $40^{\circ} \mathrm{S}$, Valdivia Province (Chile)

Etymology. Dedicated to Macarena, the daughter of Edilia, wife of the senior author.

Flight period. Specimens were captured in September, December, January and April. There are no records from other months.

\section{Hoplosauris mabillei Parra sp. nov.}

Type. Hoplosauris mabillei Holotype: 1 male Valdivia, Chile 14-9-84 Beéche coll. Allotype: 1 female Viña del Mar, Chile 23-7-1963. (MZUC-UCCC).

Material examined (19 females; 7 males). Valparaíso. Allotype: 1 female Viña del Mar, Chile 23-7-1963. (MZUC-UCCC). Paratypes: Viña del Mar: 1 female, 23-07-1953; 1 female, 25-07-1953; 2 females, 1-081953; 1 female, 8-8-1953; 2 females, 15-08-1953; 1 female 25-08-1953; 1 female 12-09-1953 (MZUCUCCC). Santiago. Peñalolén: 1 female, 15-05-1953 (MZUC-UCCC). Ñuble. Quillón Cerro Negro: 1 female, 20-09-2003 Concha coll (MZUC-UCCC). Concepción. Concepción: 1 male, 5-10-1959; Chiguayante: 1 female, 07-08-1961 Hualpén: 1 female, 28-09-2001 Parra coll (MZUC-UCCC). Malleco. Curacautín: 1 male, 20-09-1948; 1 female, 20-09-1948 (MZUC-UCCC). Osorno. Puerto Octay: 1 female, 15-07-1955 Oehrens coll; 1 female, 13-11-1955 Dehrens coll (MZUC-UCCC). Valdivia. Holotype: 1 male Valdivia, Chile 14-9-84 Beéche coll. (MZUC-UCCC).Valdivia: 1 female; 12-1964 Wagenknecht coll; 1 male, 30-04-1964 Wagenknecht coll; 1 male, 14-09-1984 Beeche coll; 1 macho, 23-09-1984 Beeche coll. Llanquihue. Maullín: 1 female, 10-11-1943 (MZUC-UCCC). Magallanes. Tres Puentes: 2 males, 02-1952 Rodríguez coll. (MZUCUCCC).

Diagnosis. Hoplosauris mabillei can be distinguished from the other species of the genus by the greenishbrown scales covering the head, thorax and abdomen. Forewing discal cell greenish-brown. Female genitalia with microspines located on the left wall and the centre of the corpus bursae. Male genitalia with long and thick spines on the vesica. These last three characters are the autapomorphies for the species.

Description. Male (Figure 1d). Head: Antennae sub-apically thickened, covered by white and dark brown scales. Vertex and frons greenish-brown. Labial palpi dark brown. Thorax: greenish-brown, as in the patagia and tegula. Tegula covered by piliform scales extending posterioly. Forewings: upperside greenish-brown. Basal line brown greenish. Terminal line, greenish-brown semicircles. Discal mark dark greenish-brown. Underside greenish-brown. Hindwings: with a hairy concave vesicle on the anal margin; upperside whitish, with some dark greenish-brown scales. Underside whitish. Discal mark light greenish-brown. Abdomen covered by dark brown and white scales. Legs chequered white and brown. Female. Similar to the male, without reduced hindwings and without a hairy concave vesicle on the anal margin. Male genitalia (Figures $6 a, c)$. Uncus straight, setose, acute apex, triangular base, approximately $1 / 2$ to length of valvae. Valvae subrectangular, with androconia at sub-apical position. Costa slightly sclerotized. Ventral margin of the valvae with little neckline. Saccus semicircular. Aedeagus tubular, vesica with two groups of long and thick cornuti. One group of spines twice the length of the other. The longest group of spines is approximately $1 / 2$ the length of the aedeagus. Female genitalia (Figure 6b). Sterigma membranous. Corpus bursae sclerotized, elongated, striated and membranous on its posterior half, with internal microspines distributed on the left wall and centre inner surface of the corpus bursae, occupying most of it. Anterior and posterior apophyses sub-equal. Ductus bursae $1 / 4$ the length of corpus bursae. Ductus seminalis discrete.

Distribution. This species occurs between latitude $33^{\circ} \mathrm{S}$ and $52^{\circ} \mathrm{S}$, in the provinces of Valparaíso and Magallanes.

Etymology. This species is named after the XIX century French naturalist, M. P. Mabille.

Flight Period. Specimens were captured in February, May, July-October and December. There are no records from other months. 

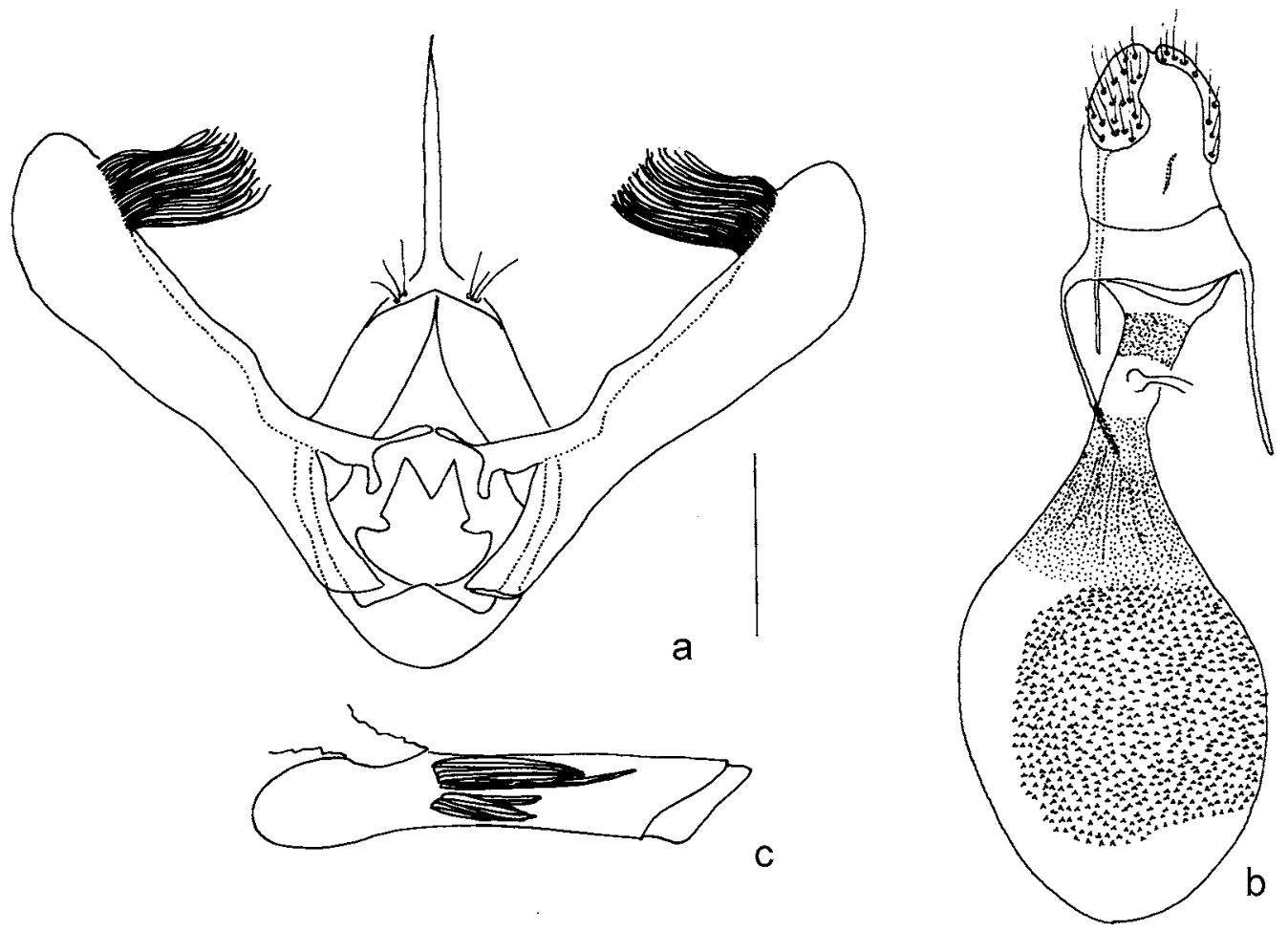

FIGURE 6. Genitalia of $H$. mabillei: a, male genitalia in ventral view; b, female genitalia in ventral view; c, aedeagus in lateral view. Scale $1 \mathrm{~mm}$.

Hoplosauris granitata (Fletcher 1953) comb. nov.

Physoloba granitata Fletcher 1953: 377; Angulo \& Casanueva 1981: 30; Scoble 1999: 755.

Type. Physoloba granitata Holotype: 1 male, Lanín Nacional Park, Pucará, Argentina (IMLT) (examined).

Material examined (15 females; 5 males). Holotype: 1 male, Parque Nacional Lanín, Pucará, Argentina (IMLT). Melipilla. Curacaví: 1 female, 23-09-2000 Solervicens coll (MZUC-UCCC). Talca. Talca: 1 male, 14-08-1997 (MZUC-UCCC). Concepción. Concepción: 1 female, 07-10-1959; 1 female, 25-08-1960; 1 female, 23-09-1976 Ruiz coll. Chiguayante: 1 female, 03-08-1961; 1 female, 07-08-1961; 1 female, 13-081961 (MZUC-UCCC). Malleco. Curacautín: 1 female, 26-08-1948 (MZUC-UCCC). Cautín. Jauja: 3 females, 23-08-1990 Carrasco coll; 2 males, 23-08-1990 Carrasco coll (MZUC-UCCC). Osorno. Osorno: 1 female, 1010-1988 (MZUC-UCCC). Valdivia. Valdivia: 1 male, 07-09-1984; 3 females, 30-09-1987 (MZUC-UCCC).

Diagnosis. Hoplosauris granitata can be distinguished from the other species of the genus by the: vesicle with a tuft of hairy scales extended towards the abdomen in the male hindwings; three long and thick bristles in the medial area of the valvae; corpus bursae with microspines distributed in centrally, spreading left. These three characters are the autapomorphies for the species.

Redescription. Male (Figure 1e). Head: Antennae sub-apically thickened, covered by white and dark brown scales. Frons and vertex with white and dark brown scales. Labial palpi brown at base, becoming white apically. Thorax: dark brown with whitish spots. Patagia and tegula with similar colour pattern. Tegula with piliform scales, extending posteriorly. Forewings: upperside dark brown, basal line grey, surrounded by dark brown scales. Medial line the same color as basal line. Postmedial line with orange circles. Terminal line represented by dark brown semicircles. Discal mark dark brown. Underside $2 / 3$ basal shining brown, apical third shiny whitish. Hindwings: vesicle concave, hairy with tuft of scales on the internal margin; tuft half the 
length of the hindwings, on the proximal margin projected posteriorly; dorsal surface whitish, ventral surface whitish; discal cell, dark brown. Abdomen covered mainly by white scales with some brown scales intercalated. Fore and mid legs with dark brown and white intercalated stripes. Hind legs white. Female. Similar to the male. Hindwing vesicle absent. Male genitalia (Figures 7a, c). Uncus curved, hairy, with acute apex, $1 / 2$ the length of the valvae. Valvae subrectangular. Androconia on the subapical region of the valvae. Three long and thick bristles are present directly ventral of the androconia. Semicircular saccus. Costa slightly sclerotized. Ventral margin of the valvae with neckline on its subapical region. Tubular aedeagus. Vesical cornuti formed by two groups of long and fine spines of subequal size, 1/4 the total length of the aedeagus. Female genitalia (Figure 7b). Sterigma membranous. Corpus bursae sclerotized and elongated, striated on its anterior half, posterior half membranous; with microspines on internal surface, distributed on its central and spreading circularly towards left area. Anterior apophyses approximately half length posteriors apophyses. Ductus bursae $1 / 4$ the length of corpus bursae. Ductus seminalis discrete.

Distribution. This species is distributed betewen $34^{\circ} \mathrm{S}$ and $40^{\circ} \mathrm{S}$ in the provinces of Melipilla and Valdivia (Chile), and the province of Neuquén, Argentina.

Flight period. Specimens were captured during the months of August and October. There are no records from other months.
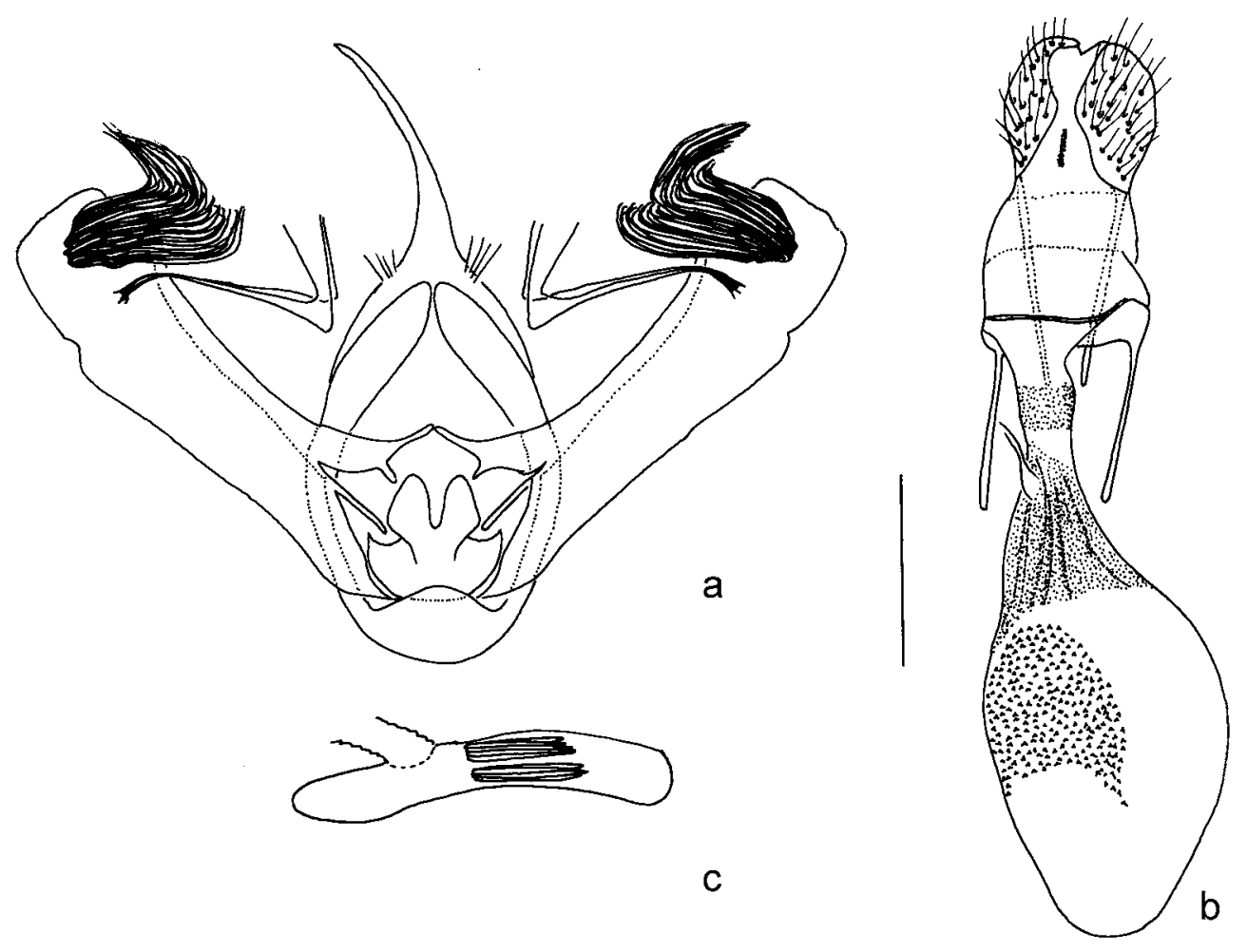

FIGURE 7. Genitalia of $H$. granitata: a, male genitalia in ventral view; b, female genitalia in ventral view; c, aedeagus in lateral view. Scale $1 \mathrm{~mm}$.

\section{Hoplosauris indistincta (Butler 1882) comb. nov.}

Amathia indistincta Butler 1882: 397; Angulo \& Casanueva 1981: 26.

Physoloba indistincta (Butler 1882) Fletcher 1953: 378; Angulo \& Casanueva 1981: 31; Scoble 1999: 755.

Rhopalodes viridularia Dognin 1906: 207; Scoble 1999: 755.

Type: Amathia indistincta Syntype: 1 female, las Zorras, Chile (BMNH) (examined). Rhopalodes viridularia Syntypes: 1 male and 2 females, Punta Arenas, Chile (USNM) (not examined). 
Material examined (21 females, 2 males). Valparaíso. Syntype: 1 female, las Zorras, Chile (BMNH). Ñuble. Chillán: 1 female, 17-10-1959 (MZUC-UCCC). Concepción. Concepción: 1 female, 01-10-1959; 1 female, 03-10-1959; 1 female, 07-10-1959; 1 female 08-10-1961; 1 female, 11-12-1964; 1 female, 29-071985 Carrasco coll; 1 female 07-08-1985 Carrasco coll. Chiguayante: 1 female, 29-10-1961; 1 female 30-101961; 1 female, 12-11-1961 (MZUC-UCCC). Malleco. Curacautín: 1 female, 07-10-1948 (MZUC-UCCC). Valdivia. Valdivia: 3 females, 30-09-1987; 1 female 21-10-1987 (MZUC-UCCC); 3 females, 30-04-1964 Wagenknecht coll; 1 female, 12-1964; Wagenknecht coll; 1 male, 30-04-1964; Wagenknecht coll; 1 male, 121964 Wagenknecht coll (UMCE).

Diagnosis. Hoplosauris indistincta can be distinguished from the other species of the genus by pale brown and white scales covering its head, thorax, forewings and abdomen. Male has a convex and hairy vesicle on the hindwings. Vesical cornuti formed by two groups of long and thin spines. One group of spines is twice the length of the other. Female with microspines arranged like a belt, encircling the corpus bursae. This character is the autapomorphy for the species.

Redescription. Male (Figure 1f). Head: Antennae sub-apically thickened, covered by dark brown and white scales. Vertex and frons covered by white scales. Labial palpi with white and dark brown scales. Thorax: light brown and white, the same for the patagia and tegula. Tegula with piliform scales extending posteriorly. Forewings: upperside white with some dark brown scales. Basal line light brown. Medial line with a dark brown spot near the anal zone. Terminal line represented by dark brown semicircles. Discal mark brown reddish. Underside light brown. Hindwings: with a hairy convex vesicle on the anal margin; upperside whitish, underside white. Discal cell absent. Abdomen covered by white scales. Fore and mid legs with dark brown and white intercalated stripes. Hind legs white. Female. Similar to the male, hindwing without hairy convex vesicle in the anal margin.

Male genitalia (Figures 8a, c). Uncus curved, hairy, with acute apex, $1 / 2$ the length of the valvae. Valvae subrectagular, slightly thicker towards the apex. Androconia on the subapical region of the valvae. Costa slightly sclerotized. Ventral margin of the valvae transversally with neckline on its subapical region. Semicircular saccus. Tubular aedeagus. Vesical cornuti formed by two groups of long and fine spines. One group of spines twice the length of the other. The group of long spines, $1 / 2$ the total length of the aedeagus. Female genitalia (Figure 8b). Sterigma membranous. Corpus bursae sclerotized and elongated, transversally striate on its anterior half. Microspines present on its internal surface, arranged like a belt, encircling the corpus bursae entirely. Posterior corpus bursae membranous. Anterior and posterior apophyses sub-equal. Ductus bursae $1 / 4$ the length of corpus bursae. Ductus seminalis indistinguishable.

Distribution. This species is distributed between $33^{\circ} \mathrm{S}$ and $40^{\circ} \mathrm{S}$, in the provinces of Valparaíso and Valdivia.

Flight period. Specimens captured during the months of April, July-December. There are no records from other months.

\section{Hoplosauris heliconoides Butler 1882}

Hoplosauris heliconoides Butler 1882: 399; Scoble 1999: 446.

Physoloba heliconoides (Butler 1882) Angulo \& Casanueva 1981: 29.

Larentia multivirgulata Mabille 1885: 70; Scoble 1999: 755.

Lobophora multivirgulata (Mabille 1885) Mabille 1891: 29.

Physoloba multivirgulata (Mabille 1885) Fletcher 1953: 378; Scoble 1999: 755, as "multivirgulata syn. heliconoides"

Type. Hoplosauris heliconoides Syntypes: 1 male, Baños de Chillán, Chile; and 1 female, Corral, Chile. (MNHN) (examined).

Material examined ( 2 females, 2 males). Chile. 1 male, Holotype Baños de Chillán (BMNH); 1 female, Allotype, Corral, (BMNH). Cautín. Termas de río blanco; 1 female, 25-12-1960 Krahmer coll.; 1 male, 13-031954 Wagenknecht coll (MZUC-UCCC). 

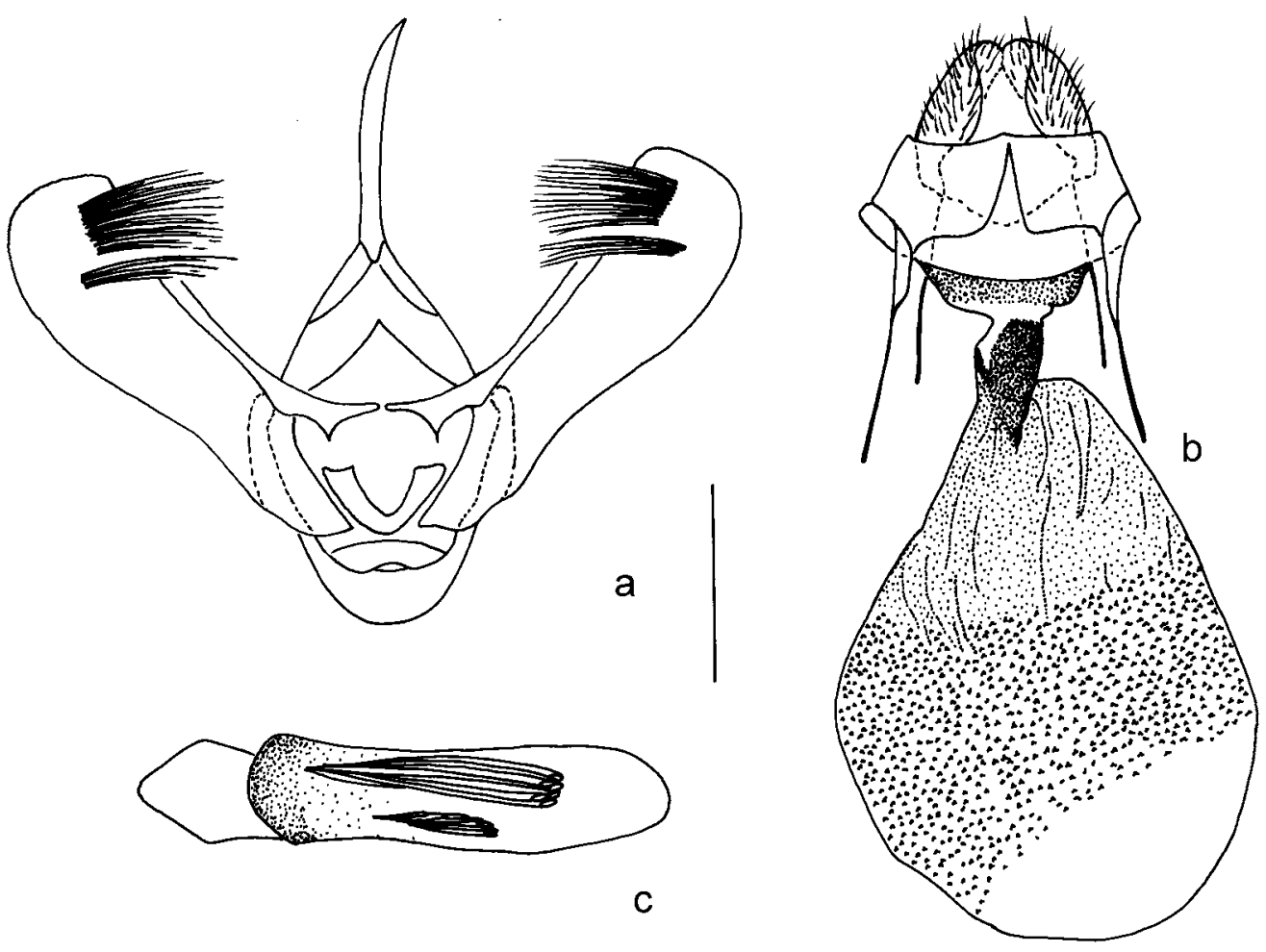

FIGURE 8. Genitalia of $H$. indistincta: a, male genitalia in ventral view; b, female genitalia in ventral view; c, aedeagus in lateral view. Scale $1 \mathrm{~mm}$.

Diagnosis. Hoplosauris heliconoides can be distinguished from the other species of the genus by the: hairy scales covering the anal margin of the hindwings; the curved valvae with an elongated costal margin; androconia formed by simple bristles plus some thick bristles. Female with ductus bursae 1/6 the length of corpus bursae.

Redescription. Male (Figure 1g). Head: Antennae sub-apically thickened, with white and brown dark scales. Vertex and frons covered by white and dark brown scales. Labial palpi with white apex and dark brown basis. Thorax: dark brown, the same colour for tegula and patagia. Tegula with piliform scales extending posteriorly. Forewings: upperside light brown. Basal line light brown. Medium line white, surrounded by dark brown scales. Subterminal line dark brown, with slightly orange spots. Terminal line represented by dark brown semicircles. Discal mark dark brown. Underside of the forewings light brown, darker towards the costal margin. Hindwings: reduced and the anal margin covered by hairy scales; upperside light brown, underside whitish. Legs white. Female. Similar to the male, without reduced hindwings and without hairy scales on the anal margin. Male genitalia (Figures 9a, c). Uncus straight, hairy, acute apex, sub-triangular base, $1 / 2$ the length of the valvae. Valvae subrectangular. Androconia on the subapical region of the valvae with long and thick bristles. Ventral, distal margin of the valvae with a longitudinal groove in the androconia region. Costa strongly sclerotized. Semicircular saccus. Tubular aedeagus. Vesical cornuti formed by two groups of long and thick spines. Spines group 1/3 longer than the total length of the aedeagus. Female genitalia (Figure 9b). Sterigma membranous. Corpus bursae slightly sclerotized and elongated; microspines covering internal surface; striated. Anterior and posterior apophyses sub-equal. Ductus bursae 1/6 the length of the corpus bursae. Ductus seminalis indistinguishable.

Distribution. This species occurs between $36^{\circ} \mathrm{S}$ and $40^{\circ} \mathrm{S}$, in the provinces of Nuble and Valdivia.

Flight period. Specimens were captured during the months of March and December. There are no records from other months. 

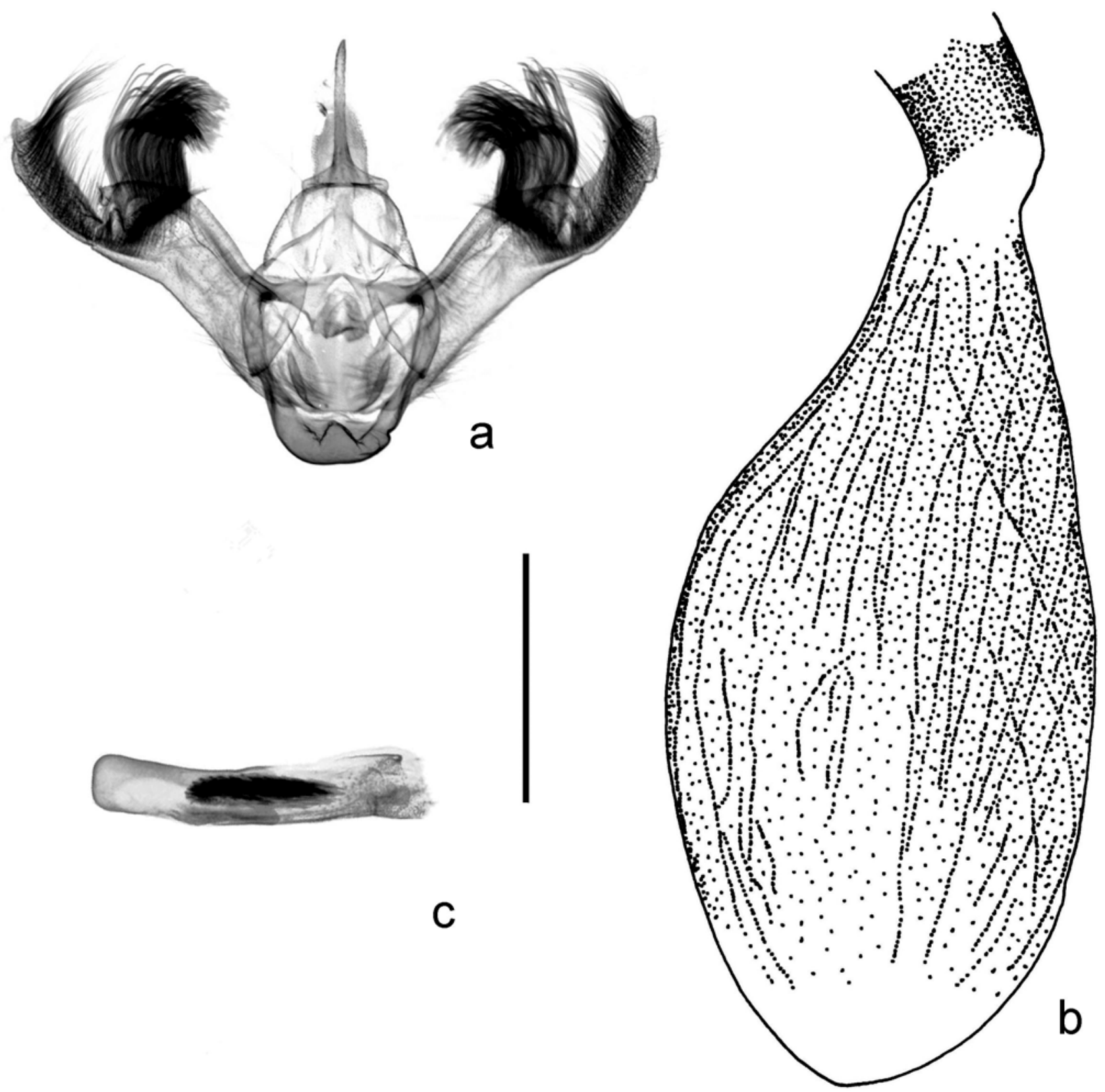

FIGURE 9. Genitalia of $H$. heliconoides: a, male genitalia in ventral view; b, female genitalia in ventral view; c, aedeagus in lateral view. Scale $1 \mathrm{~mm}$ (figs. a, c courtesy of Linda M. Pitkin).

\section{Discussion}

This study, which involves a review of morphological structures and genitalia of all relevant species, indicates that all Hoplosauris species mentioned by Scoble (1999), except for the generic type H. heliconoides should be excluded from this genus. The species $H$. moesta and $H$. alba, belong to a Larentiine tribe different from Trichopterygini. Tentatively, H. moesta and H. alba are assigned to genus Oporabia (comb. nov.). The species $H$. analogica, $H$. fragmentata, $H$. imbricaria, $H$. limnetes and $H$. perornata belong to the tribe Trichopterygini because the males have a well developed lobule on the anal margin of male hindwing. This structure also occurs in the genera Butleriana, Pachrophylla, Triptila, Fueguina (Parra 1991; Parra \& Santos-Salas 1992). 
Tentatively $H$. fragmentata and $H$. imbricaria are assigned to the genus Danielaparra, $H$. perornata to the genus Triptila, and H. limnetes to the genus Fueguina (all comb. nov.). The species H. analogica probably correspond to new genus. In summary, the following species comprise Hoplosauris: H. heliconoides Butler 1882; H. schausi (Warren 1908); H. valeria Butler 1893; H. indistincta (Butler 1882); H. macarenae Parra sp. nov.; H. granitata (Fletcher 1953); H. pachrophylloides Parra sp. nov.; H. mabillei Parra sp. nov.

The generic names Phacelophora Staudinger and Diphacelophora Berg (the latter being an unnecessary replacement name for Phacelophora) are not synonyms of Hoplosauris, as their type species Cidaria perornata does not belong to this genus. Young (2006) conducted morphological and molecular analyses of the Australian Geometridae, and included perornata. In the genitalic analysis perornata appeared to be ennomine but the molecular analysis was equivocal. Specimens of perornata are similar to species in the genus Triptila, especially in the form of the lobe of the hindwing of male and the presence of a group of dark scales in the posterior margin of the forewing. For these reasons, we maintain the species in the tribe Trichopterygini.

The current revision of species previously included in the genera Notholoba and Physoloba, indicates some of those species require transfer to Hoplosauris. Notholoba schausi, the type species of Notholoba, bears all three synapomorphic characters that define the genus Hoplosauris, and is hereby synonymized with Hoplosauris. Scoble (1999) proposed that H. edelmira Butler belonged to Notholoba, but we exclude it from the genus and the tribe Trichopterygini.

Physoloba was described by Warren (1908) for the species $P$. griseofasciata basing on specimens found in Paraná, Castro and Brazil. In this study it was not possible to study the type species of Physoloba. Although all Chilean and Argentinian Physoloba species were included in this study, Physoloba, as a genus, cannot be considered, a priori, as a synonym of Hoplosauris. Scoble (1999) included the following species in Physoloba: P. granitata Fletcher 1953; P. griseofasciata Warren 1908; P. indisticta (Butler 1882); P. insularis (Aurivillius et al. 1922); and P. multivirgulata (Mabille 1885). Because of the unavailability of types and specimens from the Juan Fernandez Islands, the species $P$. insularis was also not examined. Placement of these species must await further research.

In the genus Sauris, species have an androconia (coremata) in a subapical position in the valvae. In Sauris the coremata are paired eversible sacs typically containing long structures that presumably function in pheromone distribution, and the androconia in Hoplosauris may function similarly (Dugdale 1980). The presence of microspines on the internal surface of the corpus bursae is present in some Australian and Chinese genera (Dugdale 1980; Xue 1992). These structures are possibly similar and homologous to the microspines on the internal surface of the corpus bursae in Hoplosauris.

The species belonging to the studied genera show comparably stratified geographic distributions from latitudes $33^{\circ} \mathrm{S}$ to $52^{\circ} \mathrm{S}$, from the province of Valparaíso to Magallanes (the species $\mathrm{H}$. granitata is found in the oriental slopes of the Andes ranges, in the province of Neuquén, Argentina). Most of the species were found to be associated with the temperate forest (Northern Valdivian forest and Valdivian forest), and we suggest that the original habitat was Valdivian, with a subsequent colonization of sclerophyllous forest environments.

\section{Acknowledgments}

This research was funded by Dirección de Investigación de la Universidad de Concepción (205.113.069-1.0). The authors thank The Natural History Museum (Malcolm J. Scoble \& Linda Pitkin), U.K.; Instituto Miguel Lillo, Universidad Nacional de Tucumán, S.M. de Tucumán, Argentina (Dr. Fernando Navarro) and the Smithsonian Institution (Washington) for allowing access to Chilean material. The Museo Nacional de Historia Natural, Santiago, Chile and Museo de Zoología de la Universidad de Concepción, Chile provided dissected material. We thank Enrique Mundaca for help with English grammar. 


\section{References}

Angulo, A.O \& Casanueva, M.E. (1981) Catálogo de los lepidópteros geométridos de chile (Lepidoptera: Geometridae). Boletín de la Sociedad de Biología, Concepción, Chile, 51, 7-39.

Aurivillius, C., Prout, L.B. \& Meyrick, E. (1922) Lepidopteren von Juan Fernandez und der Oster-Insel, In: Skottsberg, C. (Ed.) The Natural History of Juan Fernandez and Easter Island. Uppsala, Almquist and Wilksells Bokthyckeri -A.-B, Vol. III. Zoology, 255-270, pl.10-11.

Butler, A.G. (1882) Heterocerus Lepidoptera collected in Chili by Thomas Edmonds, Esq. Part III.- Geometrites. Transactions of the Entomological Society of London, pp. 339-423, pl.16.

Butler, A. (1893) On a Small Collection of Lepidoptera from Chili. The Annals and Magazine of Natural History, 6, 12, 457-467.

Dognin, P. (1906) Heteroceres nouveaux de l' Amérique du Sud. Annales Societé Entomologique Belgique, 50, $204-214$.

Dugdale, J.S. (1980) Australian Trichopterygini (Lepidoptera: Geometridae) with descriptions of eight new taxa. Australian Journal of Zoology, 28, 301-340.

Felder, C. \& Rogenhofer, A. (1875) Reise der Österreichischen Fregatte Novara um die Erde (Zoologischer Theil) Band 2 (Abtheilung2), pls. 121-140. Wein.

Fletcher, D. (1953) Some new species of Geometridae from Argentina and Chile. Acta Zoológica Lilloana, 12, 367-380.

Mabille, M.P. (1885) Diagnoses de Lépidoptères nouveaux. Bulletin de la Societé Philomathique Paris, 7(9), 55-70.

Mabille, M.P. (1891) Lépidoptères. In: Mission Scientifique du Cap Horn (1882-1883). Ministéres de la Marine et de L'Instruction Publique, Paris. 6(2), 21-33.

Morrone, J.J. (2001) Biogeografía de América Latina y el Caribe. Manuales y Tesis SEA, 3,1-150.

Parra, L.E. (1991) Revisión y Filogenia del género Pachrophylla Blanchard, 1852 (Sensu Auctorum) (Geometridae: Larentiinae: Trichopterygini). Gayana Zoología, 52(2), 145-199.

Parra, L.E. (1996) Trichopterygini Neotropìcales IV: descripción de nuevos géneros y especies de Chile (Lepidoptera: Geometridae). SHILAP Revista de lepidopterología, 24(93), 37-54.

Parra, L.E. (1997) Revisión de los Lithinini y Trichopterygini (Lepidoptera: Geometridae) de Chile y de la región andina Argentina adyacente. Tesis Doctoral, Universidad de Oviedo, España, 469 pp.

Parra, L.E. \& Ibarra-Vidal, H. (1997) Taxonomía y notas biológicas de un nuevo género y especie de Geometridae de Chile (Insecta: Lepidoptera). SHILAP Revista de lepidopterología, 25(97), 53-61.

Parra, L.E. \& Santos-Salas, C. (1991) Trichopterygini Neotropicales II (Lepidoptera: Geometridae): el complejo Rhopalodes Gene, 1857. Gayana Zoología, 55(4), 267-303.

Parra, L.E. \& Santos-Salas, C. (1992) Trichopterygini Neotropicales III: género y especie nuevos para Chile (Lepidoptera: Geometridae). Boletín de la Sociedad de Biología de Concepción, 63, 151-156.

Prout, L.B. (1912) The Palaeartic Geometrae. In: Seitz, A. (Ed.) The Macrolepidoptera of the World 4(1), 181.

Prout, L.B. (1923) New Geometridae in the Tring Museum. Novitates Zoologicae, 30, 191-215.

Prout, L.B. (1926) New Geometridae. Novitates Zoologicae, 33, 1-32.

Rindge, F.H. (1987) The Eupithecia (Lepidoptera, Geometridae) of Chile. Bulletin of the American Museum of Natural History, 186(3), 269-363.

Scoble, M.J. (1995) The Lepidoptera: form, function and diversity. Second Edition, The Natural History Museum \& Oxford University Press, Xi, 404 pp.

Scoble, M.J. (1999) Geometrid moths of the world: a catalogue (Lepidoptera, Geometridae). CSIRO Publ., Collingwood, Australia - Apollo Books, Stenstrup, 1016 pp.

Warren, W. (1908) Descriptions of new species of South American Geometrid moths. Proceedings U.S. National Museum, 34, 91-110.

Xue, D. (1992) A study on the tribe Trichopterygini Warren of China (Lepidoptera: Geometridae, Larentiinae). Sinozoologia, 9, 267-298.

Young, C.J. (2006) Molecular relationships of the Australian Ennominae (Lepidoptera: Geometridae) and implicatons for the phylogeny of the Geometridae from molecular and morphological data. Zootaxa, 1264, 1-147. 